\title{
Capacities in Facing Natural Hazards: A Small Island Perspective
}

\author{
Mercy M. F. Rampengan · Agni Klintuni Boedhihartono • \\ Lisa Law $\cdot$ J. C. Gaillard $\cdot$ Jeffrey Sayer
}

Published online: 13 December 2014

(C) The Author(s) 2014. This article is published with open access at Springerlink.com

\begin{abstract}
Isolated communities on small islands are often characterized as vulnerable and marginalized. We studied the recent history of Laingpatehi, a village on Ruang Island off the north coast of Sulawesi, Indonesia to show that the marginalization-vulnerability nexus can be offset by capacity and social cohesion to enable sustainable livelihoods. The island has been impacted by volcanic eruptions, earthquakes, and competition for marine resources from mainland-based fishermen. The community has shown a remarkable ability to cope and prosper in the face of a series of external hazards. We used a sustainable livelihoods approach to identify the assets that enabled the villagers to cope. Strong social cohesion was central to the ability to organize the community and confront hazards. A diversified livelihood strategy drawing on the small island environment and its coastal and marine resources, income generating activities in a distant satellite village, and significant remittances from employment in other parts of Indonesia underpinned people's capacities to face hazards. Government assistance played a supporting role. The case of Laingpatehi demonstrates how remoteness, rather than being a source of vulnerability, can provide access to existing resources and facilitate innovation. Disaster risk reduction strategies should focus more on reinforcing these existing capacities to deal with hazards and less on physical protection and postdisaster responses.
\end{abstract}

M. M. F. Rampengan ( $)$ - A. K. Boedhihartono - L. Law · J. Sayer

School of Earth and Environmental Sciences, James Cook

University, Queensland 4870, Australia

e-mail: mercyrampengan@yahoo.com.au

J. C. Gaillard

School of Environment, The University of Auckland,

Auckland 1142, New Zealand
Keywords Human and social resources · Indonesia - Livelihood diversity · Natural hazards $\cdot$ Remote marginal communities $\cdot$ Small islands

\section{Introduction}

Vulnerability to multiple hazards is thought to be a characteristic of small, remote island communities (Lewis 2009). Their small size and isolation allegedly expose them to a wide range of internal and external hazards. Several studies have documented impacts of disasters on Small Island Developing States (SIDS) (Briguglio 1995; Méheux et al. 2007); these studies concluded that small islands are more vulnerable than non-island locations. An indicator of vulnerability of small islands has been developed by Pelling and Uitto (2001) based on the United Nations Human Development Index (UNDP 2000). They present data on disaster impacts and losses collected by the Centre for Research on the Epidemiology of Disasters. The data suggest relatively high frequencies of disasters and increased vulnerability for small islands and their populations. Additionally, many small islands are located at the geographical periphery and are socioeconomically and politically marginal (Wisner and Gaillard 2009; Kelman 2010). Their risk stems from their exposure to hazards in addition to their marginal status that reduces their ability to deal with emergencies. Some factors that contribute to their marginal status include the absence of warning systems, and institutional delays in evacuation and distribution of basic relief support (Wisner et al. 2004; Terry and Goff 2012). Wisner et al. (2012) show that small, isolated communities often receive no support or even acknowledgment of the occurrence of a disaster. 
However, some data exist regarding local capacities to cope with hazardous events. Gaillard (2007) explains how an indigenous community on Niuafo'ou in Tonga and the Aeta Negrito communities of the Philippines have coped with volcanic eruptions, and how the Tikopia in the Solomon archipelago have dealt with typhoons and famine through changes in their traditional ways of life. Experiences passed down through generations also strengthen the local capacities of Simeulue islanders who have faced many hazards, including the tsunami in Aceh on 26 December 2004 as described by Gaillard et al. (2008) and McAdoo et al. (2006). The potential for integrating local knowledge with more well-documented scientific knowledge has also been examined by several scholars (Kelman et al. 2009; Mercer et al. 2009). The use of alternative foods, as shown by a study in Fiji, reduced the likelihood of total devastation from hurricanes (Campbell 1984). Among wealthier small island regions, the Faroe Islands stand out as an example where islanders have been able to deal with isolation using their own resources (Hovgaard 2000). The Faroe Islands perform relatively strongly economically, have high levels of social services and strong municipal institutions. The people inhabit an area where the climate is relatively harsh and transportation is costly. Their economy relies heavily on fisheries. However, in the face of isolation and the associated problems with hazards, they utilize creative livelihood strategies based on local tradition, identity, and history, together with international networks to overcome threats (Hovgaard 2000).

There is a rich literature on the diverse capacities of communities-in mainland and small island communities, and in affluent and less affluent countries-in facing hazards. Wisner et al. (2012) argue that these capacities are often easier to enhance than are efforts to reduce vulnerability. Capacities are often rooted in resources that are endogenous to a community (traditional knowledge, social networks, and indigenous skills). By contrast, the vulnerability of a population often depends on access to resources that are exogenous to the community (that is, inequitable distribution of wealth and resources within the society, market forces, political systems and governance) (Gaillard 2010; Wisner et al. 2012). Therefore capacities must be recognized and used to strengthen people's strategies to face hazards. The evidence suggests that communities living in disaster prone places are able to survive and prosper in the face of potentially disastrous events and their consequences (Burton et al. 1993). They therefore must be equipped with an array of capacities, despite their vulnerabilities (Davis et al. 2004).

Yet, the positive implications hazards might have for communities are not always fully considered for small islands. Challenges can strengthen communities (Taleb 2012) and encourage them to adopt strategies that are key to building their capacities. Therefore it is important to explore how communities, particularly on the small islands of less affluent countries, use hazards and disasters to be more innovative-and how this can lead to greater prosperity. This analytical move enables a more complete picture in defining the capacities that can be beneficial in facing hazards and daily hardship. Moreover, successful community facilitation that acknowledges the strengths of a community can help craft better solutions in facing hazards and disasters.

This article contributes to understanding how communities can use hazards and disasters to strengthen their livelihoods and capacities in the realm of small island environments. It uses the case of a small community, Laingpatehi on the remote tropical island, Ruang, in North Sulawesi, Indonesia. Laingpatehi fits both the UNESCO (1992) and Indonesian Coastal and Small Island Management Act 2007 (Article 1 item 3 Law 27/2007) definitions that categorize "small islands" as those with an area equal or less than $2,000 \mathrm{~km}^{2}$. This study examines the qualities that have enabled this community to deal with a series of natural hazards. We describe the ways in which the people of Laingpatehi have coped with the dynamics of their small island environment. We argue that more attention needs to be given to strengthening existing local capacities to face internal and external hazards and less to postdisaster responses or physical protection measures.

\section{Capacities of Small Island Communities}

Many small island communities have survived for generations in remote, hazard prone locations (Reenberg et al. 2008; Campbell 2009; McAdoo et al. 2009; Mercer and Kelman 2010). Campbell (2009) lists natural hazards that Pacific islanders have endured for generations, such as storms, tidal surges, typhoons, tsunamis, erosion of coastal materials, and a diversity of other hazards. Nonetheless, they continue to live in coastal and small island places. This suggests that the benefits they derive from the resources found there outweigh the risks (Cannon 2008; Kelman and Mather 2008). Yet hazards that trigger disasters are regular occurrences. Communities have thus developed the capacity to face hazards, where capacity is understood as "the set of knowledge, skills and resources people resort to in dealing with natural hazards and disasters" (Cadag and Gaillard 2013, p. 269). The capacity to reduce the impact of extreme events has been recognized by several scholars (Campbell 2006; McAdoo et al. 2006; Veitayaki 2006; Gaillard and Le Masson 2007; Gaillard et al. 2008; Campbell 2009; Schwarz et al. 2011). It is suggested that communities have traditions that enable them to cope with disasters (Campbell 2006). These 
traditions have been built on beliefs and behaviors over long periods and underpin the fabric of their societies (Paton 2006; Campbell 2009). Hazards are a common part of life (Bankoff 2004; Campbell 2009; Lewis 2009; Kelman et al. 2011) and people are able to persist and prosper in hazardous situations (Burton et al. 1993).

The importance of culture in dealing with disasters has been well documented in both affluent and less affluent countries (Hewitt 2009). Chester et al. (2008) have shown the role of religion among residents living around Mt. Vesuvius and Mt. Etna, Italy during the eruption of these volcanoes. Lavigne et al. (2008) provide evidence of the role of cultural beliefs in influencing the behavior of people subject to volcanic activities around Mt. Merapi in Central Java, Indonesia. Such culture is shaped by the nature of human environments (Cosgrove 1996). This literature shows both how culture is shaped by hazardous events, and how culture plays an important role in dealing with such events.

Communities generally have strong local cultures that allow for concerted social action (Mitchell 1995) to address an inherently difficult environment. Social action, shaped by both physical and psychological experiences, is important in understanding at-risk communities (Cronin et al. 2004; Becker et al. 2008; Kelman and Mather 2008). Small size and isolation are variables that have been seen to contribute to a spirit of solidarity and a sense of community (Anckar and Anckar 1995). Failing to recognize the local cultural context reduces the effectiveness of disaster risk reduction (Hewitt 1983).

The capacity to deal with natural hazards can be usefully understood through livelihood strategies (Chambers and Conway 1992; Scoones 1998; Ellis 1999; Mula 1999; Sanderson 2000; Twigg 2001; Cannon et al. 2003; Gaillard and Le Masson 2007; Coulthard 2008; Gaillard et al. 2009; Binternagel et al. 2010). Scoones (1998), for example, identifies three important livelihood strategies: agricultural intensification/extensification, livelihood diversification, and migration. Such strategies enable communities to spread risk and cope with shocks while maintaining the availability of resources that support their lives. Ellis (1999) and Gaillard et al. (2009) argue that these strategies provide the flexibility and stability important for sustainability over time and enable people to cope with changing conditions. These strategies enable a reduction in risk, so they can continue their lives and maintain their culture.

Local culture that supports sustainable livelihoods thus plays an important role in allowing people to cope with multiple hazards. Culture is part of a community's livelihood resources and shapes local perceptions, concerns, and behaviors in times of disasters (Mercer et al. 2012). Culture allows members of communities to act in concert to cope with changing environments (Duncan and Duncan 1996).
Cultural values allow communities to respond to hazards (Cronin et al. 2004; Becker et al. 2008; Kelman and Mather 2008).

A community's capacity to face hazards is not isolated from government support, across various scales (Wisner 2003). Government support is needed to strengthen local capacity. Wisner (2001) illustrates this point with an example from the recovery process in El Salvador after Hurricane Mitch in 1998. The community's capacity is dependent upon accessibility to resources that can often be under government control (Wisner et al. 2004; Chambers 2006). If government support is not in-line with the community's needs, this could be a catalyst for further hazards. One example is the experience of survivors of the Payatas trash slide in the Philippines (Gaillard and Cadag 2009). Another example is documented by Campbell (1984) who explains how the introduction of unsuitable, imported foods created new vulnerabilities for Pacific island communities facing future hurricanes. The case presented here supports the importance of considering local perceptions that have implications for the methodology of this study.

\section{A Framework for Understanding Capacities of Small Island Communities}

Wisner et al. (2012) have developed an approach to understanding people's capacities based on a sustainable livelihoods framework. Capacity is described in terms of natural, political, economic, social, physical, and human resources (Wisner et al. 2012). Figure 1 illustrates how we have adapted this conceptual framework for analyzing the ways in which island communities deal with hazards. Our use of this framework is appropriate for several reasons. The framework accommodates "non-Western, oral and vernacular understandings" (Wisner et al. 2012, p. 28). These understandings are important to exploring local capacity in this study, and are reflected in the use of participatory tools. The framework also allows the use of livelihood resources to understand local capacity. The way in which communities utilize their resources in facing hazards is an integral part of day-to-day life, and is reflected in the framework. Therefore it fits the core focus of this study.

The framework shows the ways in which resources are interlinked (Sayer and Campbell 2004) and combine to determine capacity. The links (arrows) among resources show the connections and/or trade-offs (the fluidity of assets) among resources (Sayer and Campbell 2004; Scoones 2009). Capacity is thus determined by the combination and integration of the assets or attributes that provide the ability to face hazards. Capacities are not only related to the existence of resources but include the ability to either 
Fig. 1 Conceptual framework for analyzing the capacity of small island communities to cope with hazards. Source: Adapted from Wisner et al. (2012, p. 28)

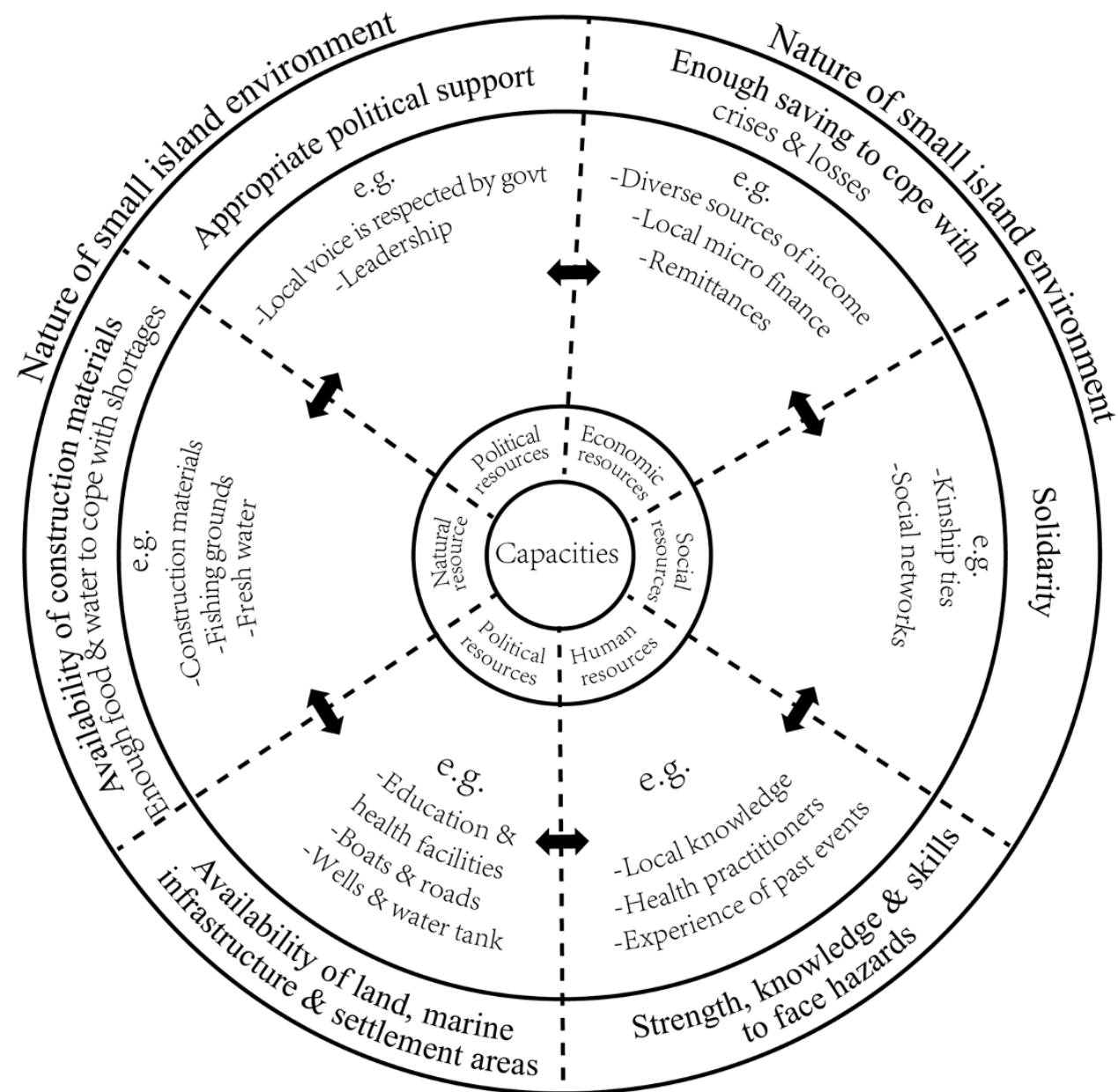

use or access resources (Sen 1981; Watts and Bohle 1993; Kuban and MacKenzie-Carey 2001). Availability and access to resources defines how diverse and sustainable people's livelihoods are and determines their ability to face hazards (Gaillard et al. 2009).

The outer layer shows the outcomes based on the resources identified. These resources help communities strengthen their livelihood strategies, which in turn shapes outcomes in the context of small island environments. This pathway from livelihood resources to livelihood outcomes through livelihood strategies is described by Scoones (2009).

\section{Study Locations}

The present study focuses on the Archipelagic District of Siau Tagulandang Biaro (referred to by the acronym Sitaro) in North Sulawesi Province, Indonesia (Fig. 2). Sitaro consists of 47 small islands, of which 10 are permanently inhabited. The population is approximately 63,801 , of whom $64 \%(40,758)$ live on Siau Island, the administrative principal island of Sitaro (Badan Pusat Statistik Kabupaten Kepulauan Sitaro 2012). Sitaro is an archipelago of volcanic oceanic islands that arise from the sea floor at a depth of over $1,000 \mathrm{~m}$ within the Sangihe arc (Shekelle et al. 2008). The islands experience volcanic eruptions (lahar, lava, and pyroclastic flows), landslides, earthquakes, tsunamis, floods, coastal erosion, strong winds and droughts (Departemen Pekerjaan Umum Republik Indonesia 2008; Badan Perencanaan Pembangunan Daerah Kabupaten Kepulauan Sitaro 2010b; Badan Perencanaan Pembangunan Daerah Kabupaten Kepulauan Sitaro 2012; Badan Perencanaan Pembangunan Daerah Kabupaten Kepulauan Sitaro 2010b). Sitaro District has a total area of $3,066.22 \mathrm{~km}^{2}$, of which only $9 \%$ is land mass $\left(275.96 \mathrm{~km}^{2}\right.$ ) (Badan Perencanaan Pembangunan Daerah Kabupaten Kepulauan Sitaro 2010b) and lies roughly midway between the Sulawesi mainland and the larger island district of Sangihe. Sitaro attained district status in 2007, previously having been part of Sangihe District. Two of the islands (Siau and Ruang islands) have active volcanoes.

The study focused on Laingpatehi village on Ruang Island. Laingpatehi is approximately $110 \mathrm{~km}$ from Manado 
Fig. 2 Map of Sitaro District, North Sulawesi Province, Indonesia, showing locations mentioned in the text. District of Sitaro is shown by the rectangular dotted lines. Manado is the capital city of North Sulawesi Province. Bitung and Tomohon are satellite cities within North Sulawesi Province. Other squares show principal cities in other provinces

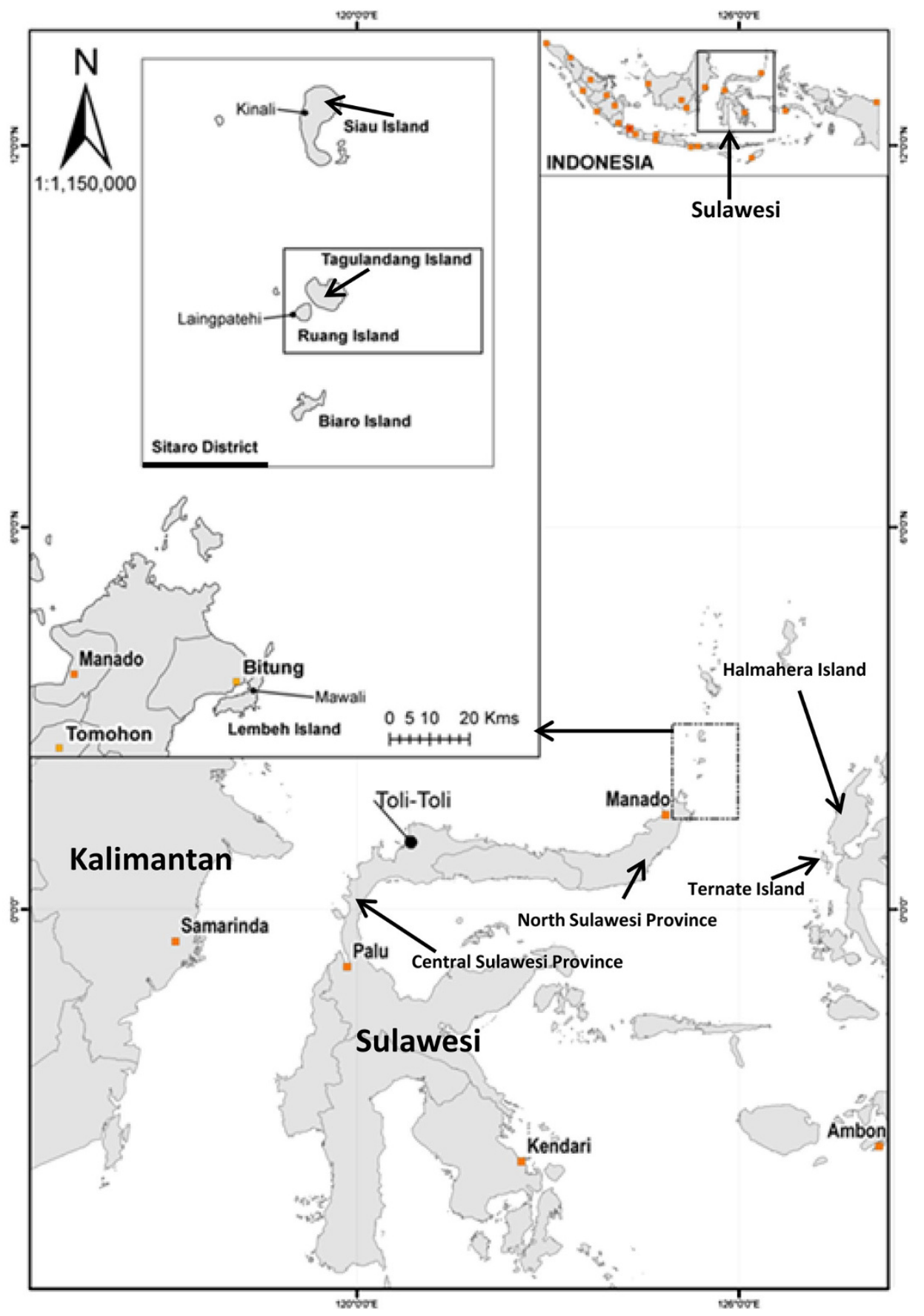

(Paris et al. 2014), the capital city of North Sulawesi Province, $40 \mathrm{~km}$ from Siau, the district capital, and $4 \mathrm{~km}$ from the closest town Bahoi (town of Tagulandang subdistrict, which is the center of the administration area of Laingpatehi village) on the island of Tagulandang. Ruang has an area of 1,426 ha and has only two villages, Laingpatehi and Pumpente with a total population of 843 (Kantor Kecamatan Tagulandang 2011). Pumpente was part of Laingpatehi village until 1998. Both villages share the same biophysical condition of Ruang Island, hazards, and disaster impacts. Sangir is the dominant ethnicity in both villages, and Christianity is the majority religion. For logistic and time constraint reasons, Laingpatehi was chosen as our study location. Laingpatehi village occupies 8 ha and has 103 ha of cropland. Laingpatehi has 122 households with 522 community members, of whom 266 are male and 256 female (Kantor Kecamatan Tagulandang 2011). The village economy relies mostly on fishing 


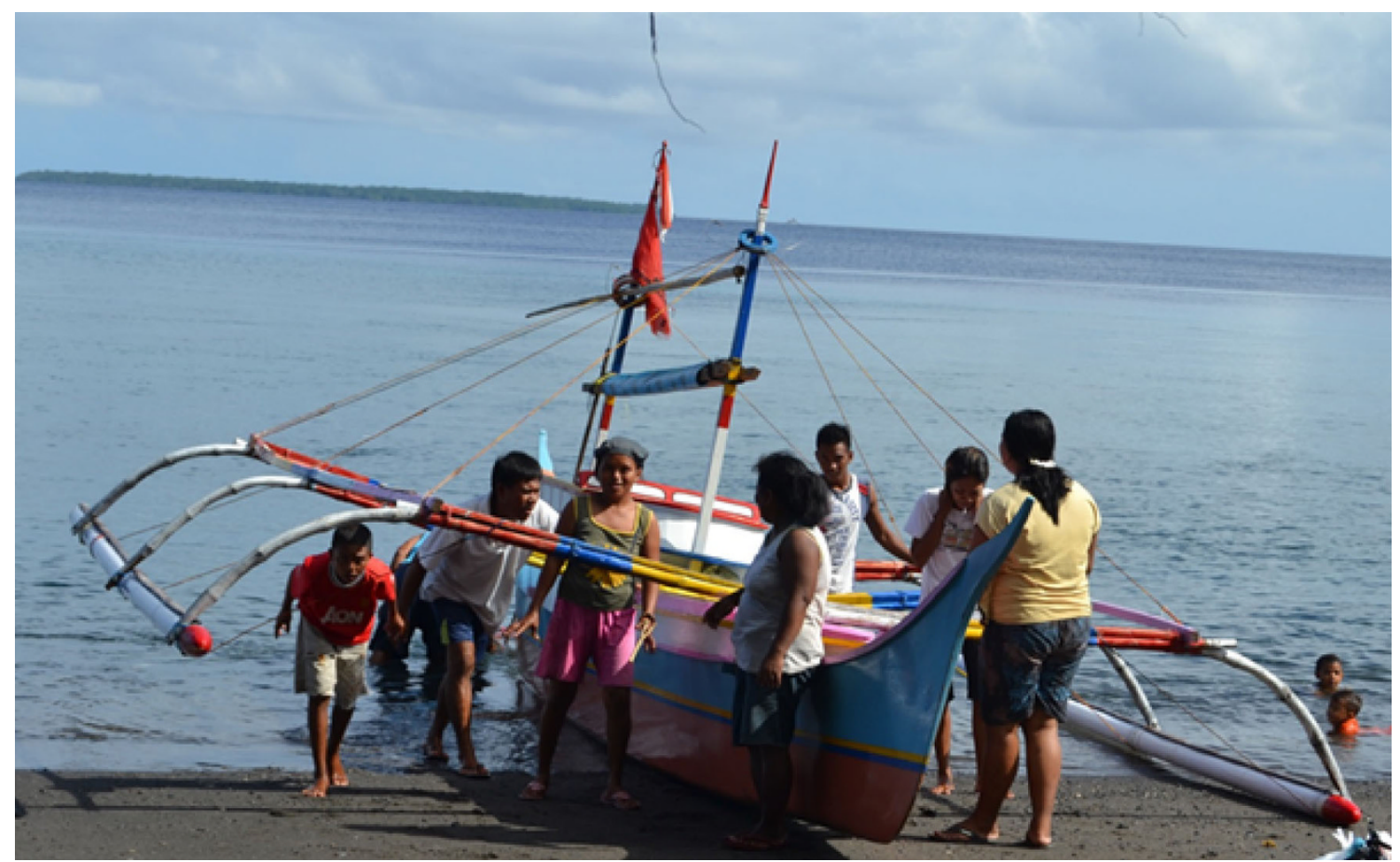

Fig. 3 Fishermen in Laingpatehi village, Ruang Island, North Sulawesi Province, Indonesia cooperating to bring a sande boat (longline boat) ashore. Photograph by Mercy M.F. Rampengan, July, 2012

(Fig. 3). Remittances from villagers who work as sailors, mostly in Kalimantan, also provide a source of income and support local church development. In recent years people from the village have made seasonal migrations to Laolalang, a satellite village (some villagers visit seasonally, and some villagers live there permanently) the people of Laingpatehi established approximately $550 \mathrm{~km}$ away in Toli-Toli, Central Sulawesi Province (Fig. 2) where they farm cloves and nutmeg.

\section{Methods}

There has been little research on the small islands of Eastern Indonesia and no major studies were found that have examined their capacity to face natural hazards. The present study is based on fieldwork conducted from June to December 2012, with preliminary visits in November 2011 and January 2012. The preliminary visits provided a basic understanding of the communities and their environment and allowed the principal author to develop links with the local people (head of village and Church leaders) and government institutions. The last visit (August to October 2013) facilitated the confirmation of findings from previous visits, deepening and strengthening the validity of the findings and preliminary analysis.

Marshall and Rossman (2006, p. 77) explain that "Gaining access to sites requires time, patience and sensitivity to the rhythms and norms of a group." In order to gain the acceptance of the community (Swanson 2008) a presentation on the purpose of the study was made during a Sunday service in the local church during the second visit. Research was conducted in the local Manadonese language. The principal author also took part in Mapalus-a local name for informal cooperative social work in the community. Mapalus is a form of social cohesion that supports communities in times of hardship, farming, and fishing activities, as well as village development. The lead author lived in the village during the study and attended a number of church events. Data for the research were collected using standard participatory methods (Kumar 2002; IFRC 2007; Dazé et al. 2009). Observations of the community's daily activities were documented to help understand the context in which participatory activities took place. Semistructured interviews explored physical and community resources and provided information that was too sensitive to discuss in group activities, such as personal beliefs about phenomena that happen during disasters. Overall, 25 community members were individually interviewed (six female, 19 male). The combination of opportunistic and snowball techniques (Kemper et al. 2003) facilitated a flow of information and helped identify appropriate informants for specific issues. Participants were chosen based on their availability and interviewed in locations convenient for them. Interviews were held after the participatory activities because some issues needed greater exploration. During the last visit, two 
Table 1 Schedule of the main participatory activities and confirmation of findings conducted in Laingpatehi village, Ruang Island, North Sulawesi Province, Indonesia, July 2012-November 2013

\begin{tabular}{llllc}
\hline Meetings & Frequency & Location & Date & Participants \\
\hline Concept mapping & 5 & Church, house, and under a tree & $1 / 07 / 2012$ & 13 \\
& & & $3 / 07 / 2012$ & 10 \\
& & $4 / 07 / 2012$ & 9 \\
& & & $9 / 07 / 2012$ & 5 \\
& & & $23 / 10 / 2012$ & 5 \\
Historical timeline & 1 & On the beach & $13 / 10 / 2012$ & 7 \\
Seasonal calender & 1 & In a garden & $13 / 10 / 2012$ & 7 \\
Venn diagram & 3 & House, on the beach, & $6 / 07 / 2012$ & 10 \\
& & and in a kiosk & $6 / 07 / 2012$ & 5 \\
& & & $13 / 10 / 2012$ & 7 \\
Livelihood assets & & Under a tree & $18 / 10 / 2012$ & 6 \\
Vulnerability matrix & 2 & Church and under a tree & $4 / 07 / 2012$ & 9 \\
& & & $18 / 10 / 2012$ & 6 \\
Confirmation of findings & 2 & Under a tree and in primary & $9 / 09 / 2013$ & 15 \\
& & school building & $11 / 09 / 2013$ & 33 \\
\hline
\end{tabular}

meetings took place with the community of Laingpatehi to confirm the findings (Table 1). Secondary data were collected from documents and reports published by government agencies and from regional newspapers.

The ultimate objective of this study was to explore people's livelihood strategies, with special emphasis on their ability to cope with hazards such as volcanic eruptions, coastal erosion, earthquakes, droughts, and high wind. This required a bottom-up approach, taking into account locality and context (Chambers 1994; Ivanitz 1999), and a recognition of people's perspectives and priorities (Rahman and Fals-Borda 1991; Scoones 2009). By using various participatory tools (Kumar 2002) in an interactive and collaborative way to investigate problems (Ivanitz 1999), we uncovered the community's capacity, using language that emphasized assets and strengths. This helped increase the level of engagement with participants and made explicit the attitudes and behavior of the practitioners involved (Chambers 1994; Kumar 2002).

The series of participatory activities (Table 1) conducted with local people included participatory mapping (mapping people's knowledge about their current capacities related to livelihoods and hazards); an historical timeline (what has happened in the past to track changes in the environment, livelihoods, and village development); the seasonal calendar (to explore the changes taking place in the community over the period of one year); and venn diagrams to understand the roles and services of internal and external institutions, as well as the suitability of their assistance. The livelihood assets framework was used to identify important resources, and a vulnerability matrix was developed to determine important hazards.

Participatory exercises in larger groups were held in the church. However, it proved difficult to gather people in bigger groups except on Sundays when they did not fish or cultivate. Therefore, following Chambers (1994), a flexible approach was taken and meeting locations were changed to use the villagers' typical informal convening places such as on the beach, in front of their houses, under a tree, or in a garden. This limited the intrusiveness to daily activities, which made interviewees more comfortable and willing to share their perspectives. We avoided establishing a fixed time schedule and provided people with contexts where they could talk freely. The changing places, group sizes, and flexible time schedules enabled participants to continue with their daily activities, such as cleaning fishing equipment and looking after their small kiosks while discussing issues and doing participatory exercises. This flexible approach is appropriate, fair, and important to uncover local capacities. Activities were organized on the islanders' terms and valued their perspectives. During the course of this flexible approach, discussions became far more relaxed as personal relationships and trust were built.

Villagers from Laingpatehi reacted positively to the approaches used and showed confidence in sharing information on their capacity and on the threats that affect their livelihoods. The discussions during the participatory activities were documented and later analyzed together with observations of daily life.

\section{Historical Account and Livelihood Dynamics}

The name "Laingpatehi" comes from the local Sangir language. "Laing" means cape and "Patehi" means observation. So Laingpatehi means the cape where people were able to observe the weather on their fishing grounds (Taman Budaya Manado 1991). The villagers reported that, from the 


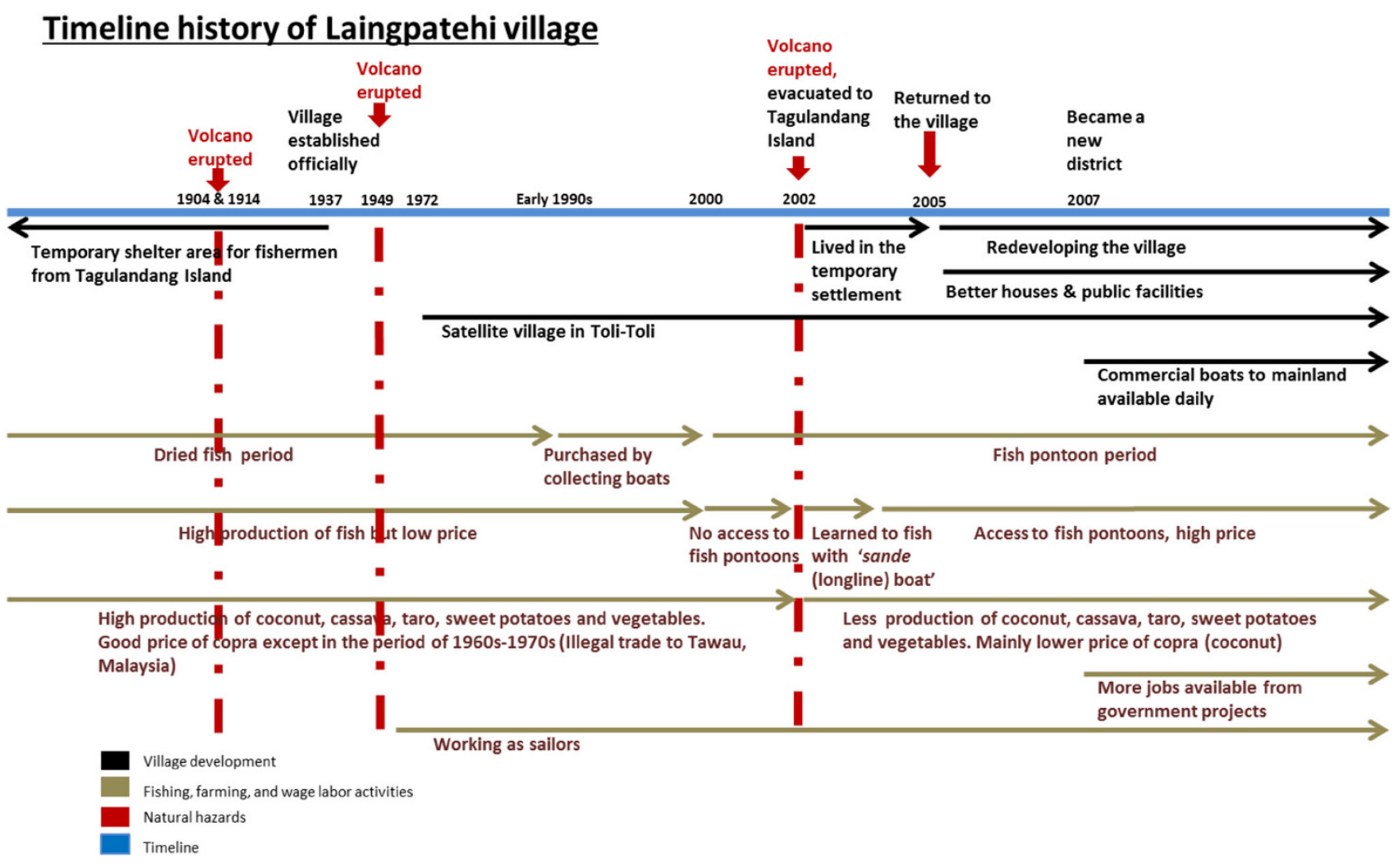

Fig. 4 Historical events influencing Laingpatehi village, Ruang Island, North Sulawesi province, Indonesia, 1904-2007 (derived from historical timeline activities with the villagers)

1800 s to the early 1900 s, fishermen from Tagulandang Island used Ruang as a transit area and for temporary shelter during their fishing trips. They built temporary houses called daseng on the island. The village was established officially in 1936 and 1937 when a church and primary school were built. Figure 4 summaries the livelihood history and village development of Laingpatehi. It shows the dynamic livelihood strategies adopted by the villagers to cope with the natural hazards their island is subjected to. Volcanic eruption was the biggest concern of the villagers, although other hazards (such as strong winds) were acknowledged by villagers as a fact of life for people living on a small island.

Sitaro is claimed to produce the world's best quality nutmeg (Badan Perencanaan Pembangunan Daerah Kabupaten Kepulauan Sitaro 2010a) (Fig. 5). Indonesia is the biggest producer of nutmeg in the world, and between onethird and one-half of its production comes from Siau Island alone (Marks and Pomeroy 1995). Siau is a center of nutmeg diversity (Hadad and Hamid 1990), with the best quality and highest productivity among other regions in Indonesia (Novarianto 2010).

Villages in the Sitaro islands therefore derive significant income from nutmeg, in addition to other agroforest products. In contrast, Laingpatehi has always been a fishing village and has no nutmeg plantations because the soils are unsuitable.
Villagers' reports, government documents, and observations made during the fieldwork all suggest the soil is not suitable for planting most cash crops because it consists of a deep gravely, impenetrable layer of rock substrate. In order to exploit the income earning possibilities of nutmeg and to provide a larger area for settlement, the people of Laingpatehi established a satellite community on the mainland of Central Sulawesi Province in 1972. This village is called Laolalang and is located in the District of Toli-Toli (Fig. 2). This was an entirely local initiative with no support from government, and reflected a lack of arable land on Ruang. In interviews and participatory activities, Laingpatehi people suggested they had become familiar with Toli-Toli when they were involved in the illegal trade (1960s-1970s) of copra, nutmeg, and cloves purchased from other islands. These products were being smuggled to Tawau in Malaysia where prices were higher and not subject to Indonesian government controls. Traders from Tawau strengthened the villagers' cooperation by providing them with boat engines, temporary accommodation in Tawau, help with logistics, and households goods. In this way the villagers diversified their economy and were able to gain income from tree crops at times when fishing was less profitable. After the introduction of increasingly strict border controls from both countries' government agencies this activity was stopped. 


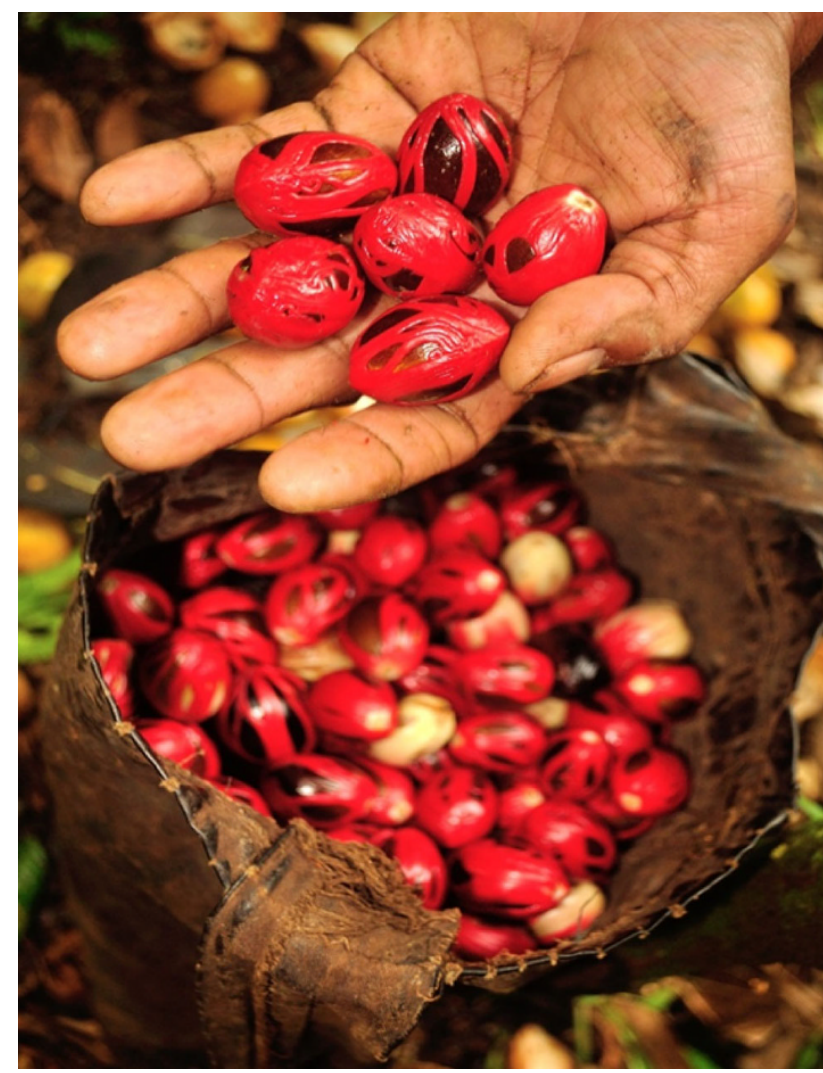

Fig. 5 Nutmeg, here shown on Siau Island, North Sulawesi Province, Indonesia, is a main source of income on the other islands in the Sitaro archipelago. Photograph by M. Irfansyah Lubis, August 2013. Reproduced with the kind permission from M. Irfansyah Lubis

Villagers reported that people moved to Laolalang when fishing was poor or to harvest their tree crops. People from Laingpatehi also migrated to Halmahera Island (North Maluku Province) in 1952 and Bolaang Mongondow District (mainland-North Sulawesi Province) in 1976 as part of government resettlement programs, but these people now have reduced links with Laingpatehi. People from Laingpatehi now live in many parts of Indonesia (Fig. 6). Most of these migrants remain in regular contact with Laingpatehi and many remit money to their families in the village. That tight connection and high commitment to their homeland (Tuan 1974; Le De et al. 2013) is a common distinctive cultural feature of small island inhabitants (Beller 1990; Giavelli and Rossi 1990).

The strong social fabric among villagers of Laingpatehi village also provided job opportunities for villagers. About 30 villagers work on ships, mostly in Kalimantan. When people get jobs away from the island, they facilitate the entry of other villagers to this specialized labor market. Villagers explained that remittances from workers on ships support the church and enabled villagers to purchase building materials and household appliances. However, it was ethically problematic to attempt to quantify the remittances as villagers were reluctant to provide details. Remittances take many forms and are difficult to track, especially as sailors bring money or building materials and household appliances to their families during their visits.

Until the early 1990s, Laingpatehi village produced salted and dried fish (Fig. 4) caught by purse seining (known locally as pamo) (Fig. 7), and cultivated a limited amount of copra. Villagers organized themselves into groups because purse seining requires teams of people. They salted and dried the fish, but at times the fish were so abundant that the villagers were unable to process everything they caught, and the excess was buried on the beach. Fish prices at this time were low because of the absence of markets close to their island, and there was no ice or cold storage or electricity on the island. Thus their level of economic development was low. As Brookfield (1990) argues, the development of the economy may be hindered in small island areas if producers are local but consumers are not. So distance and access to markets in the case of fishing production in Laingpatehi were the key constraints of economic development in that era.

Processed fish and copra were taken to mainland $\mathrm{Su}-$ lawesi by sailboats and some villagers drowned because of storms. Since the 1990s, middlemen in the mainland towns of Bitung and Manado have sent collecting boats to buy fresh fish (Fig. 4). Since 2000, people from the mainland of Sulawesi have begun to develop fish pontoons around the traditional fishing grounds of Ruang (Fig. 4). A fish pontoon is a kind of fish aggregation device comprised of three parts: the buoy on the surface of the sea; the line and attracting device (coconut leaves) that hangs in the middle and sways in the current to attract fish; and the anchor that sits on the seafloor to ensure the pontoon does not float away. This has reduced fish populations in the pamo fishing area. Villagers reported that fish pontoons block the access of target fish to the catching area of the pamo boats. Pamo fishing is therefore no longer profitable. Respondents reported that conflicts occurred with mainland Sulawesi fishermen when they prevented the Laingpatehi people from purse seining around the fish pontoons.

\section{Livelihood Dynamics and Natural Hazards}

Ruang is a volcanic island. Mt. Ruang is $722 \mathrm{~m}$ above sea level, 1,700 $\mathrm{m}$ above the ocean floor (Fig. 7), and is active (Morrice et al. 1983). Eruption records go back to 1808 . There were 13 major eruptions from 1808-2002 (Table 2). The eruption in 1871 triggered a tsunami that struck Tagulandang Island and killed about 400-450 people, including the King of Tagulandang (Brilman 2000; Manginsela-Tiendas 2001; GVP 2013; Paris et al. 2014). 


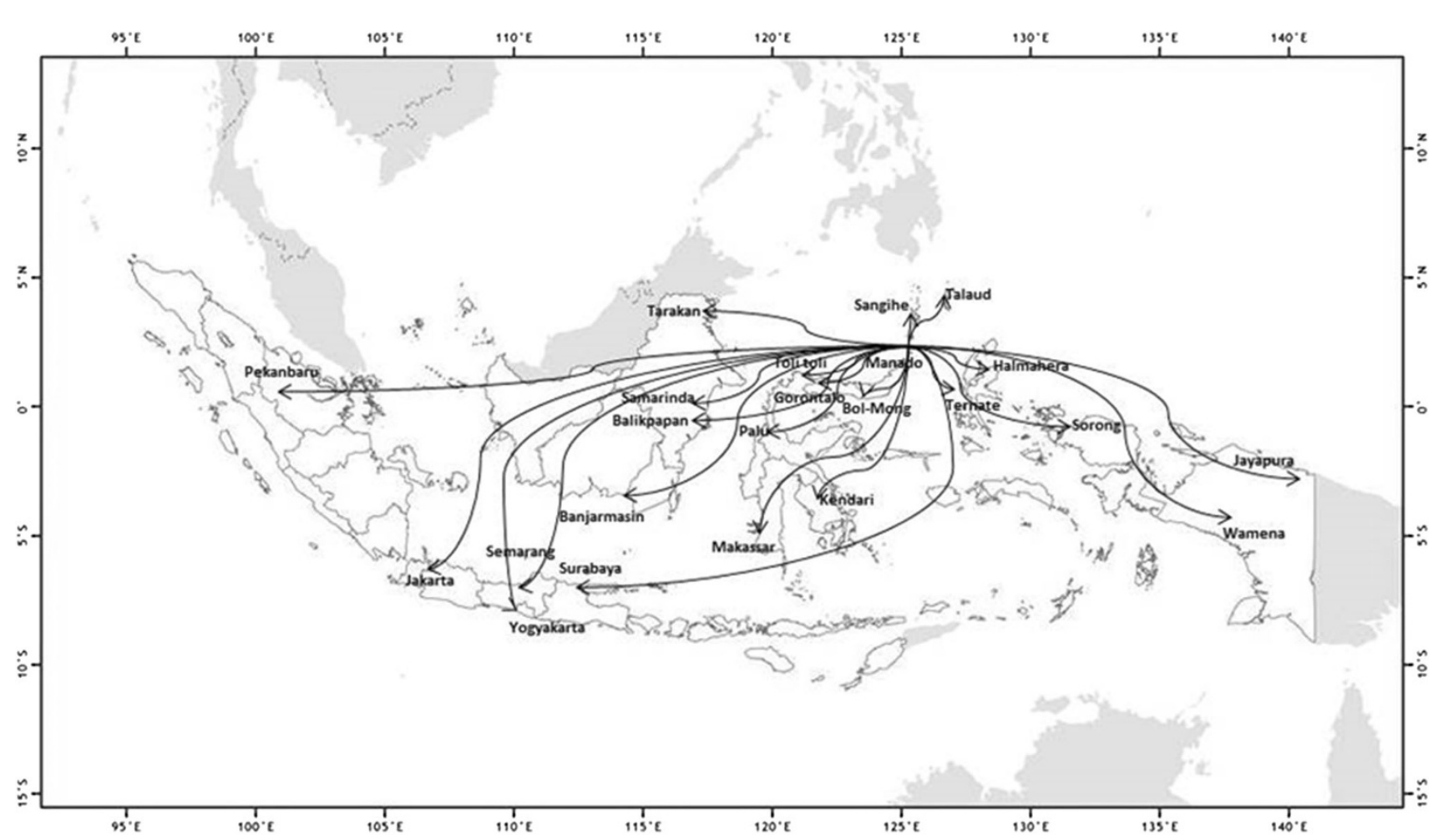

Fig. 6 The distribution of out-migrants from Laingpatehi village, Ruang Island, North Sulawesi Province, Indonesia, throughout Indonesia (based on participatory activities and interviews with the villagers)

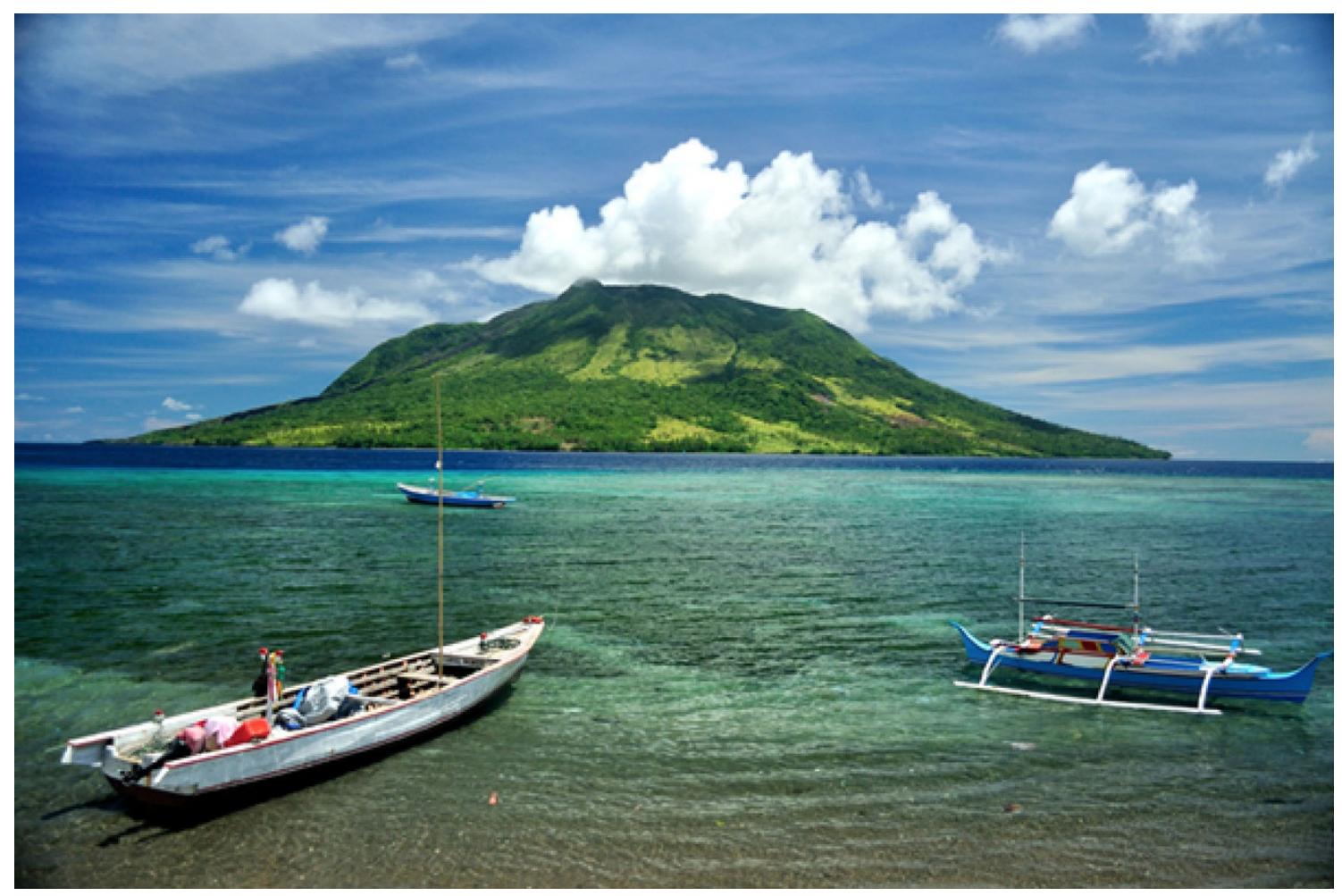

Fig. 7 Ruang Island as seen from Tagulandang Island, with a pamo boat (left) (purse seine fishing) and sande boat (right) (longline fishing). Photograph by M. Irfansyah Lubis, September 2013. Reproduced with the kind permission from M. Irfansyah Lubis 
Table 2 History of Mt. Ruang eruptions (1808-2002) (Adapted from Brilman 2000; Manginsela-Tiendas 2001; GVP (Global Volcanism Program) 2013)

\footnotetext{
*VEI volcanic explosivity index
}

$\begin{array}{ll}\text { 15 Nov 1874 } & \begin{array}{l}\text { Explosion \& pyroclastic flow } \\ \text { Formation of lava dome }\end{array} \\ \text { 22 Apr 1904-27 May 1905 } & \begin{array}{l}\text { Explosion, pyroclastic flow, lava, } \\ \text { lahar } \\ \text { Explosion, pyroclastic flow, lava } \\ \text { ash } \\ \text { Explosion, lava flow, formation } \\ \text { of lava dome } \\ \text { 29 May 1914-28 Feb 1915 } \\ \text { 5-19 Jan 1949 }\end{array} \\ \text { 27 Jun 1996 } & \begin{array}{l}\text { Explosion } \\ \& \text { lahar }\end{array} \\ \text { 25-29 Sept 2002 } & \end{array}$

Villagers reported that the last eruption in 2002 was preceded by earthquakes on 24 September, followed by a thick volcanic ash emission the next day. All villagers from Ruang Island were forced to evacuate to Tagulandang Island and one died during the evacuation. On the night of 24 September, before they evacuated to Tagulandang, the villagers congregated in their local church, prayed together, and discussed the organization of their evacuation. Elders, women, people with disabilities, and children were evacuated first. They used all the boats in the village and additional boats from Tagulandang Island. Several villagers initially refused to move, but approaches from other villagers and government officers finally resulted in their agreeing to leave. The evacuation was completed a few hours before the main eruption on the afternoon of 25 September.

The entire population of the village lived in a temporary settlement on Tagulandang for three years before officially returning to Ruang in 2005. The village officer and villagers explained that about 27 , mostly older, people died during the temporary settlement, reportedly from acute depression-related diseases. These depression-related deaths were a direct result of the material and emotional impacts of the disaster: homes destroyed; coconut trees obliterated; familiar places left for "temporary" (but in reality multiyear) quarters; spiritual separation from the gravesites of loved ones and the home of ancestral spirits; lives and social connections altered and interrupted; independence replaced by a dependent status .

The people reported that the government provided adequate basic support (that is, food, clothes, blankets, and health services) when they lived in the temporary settlement on Tagulandang Island. The government had planned to relocate all the villagers to Biaro Island (Makanoneng 2012). This plan was rejected by the community because of a lack of facilities, access to markets, and arable land on Biaro. The people preferred to return to Ruang. It appears from the villagers' explanations that the main reason was the desire to maintain the integrity of the community.

While they were living in the temporary settlement the villagers met fishermen from Ternate (North Maluku Province) as well as fishermen from other islands. Laingpatehi people learned from them how to build and use longline boats (known locally as sande) (Fig. 7). The new ability to use this longline fishing technique enables the Laingpatehi people to access fish pontoons and has provided them with increased income. In addition they were able to target fish species through the use of sande that pamo fishermen were not able to catch and were thus able to dictate fish prices in Tagulandang market. Fishermen from Tagulandang Island mostly focus on reef fish. Purseseine fishermen who did not convert to longline fishing became carpenters, builders, boat taxi operators, or fish dealers. 
Fig. 8 Capacity framework for Laingpatehi village, Ruang Island, North Sulawesi Province, Indonesia

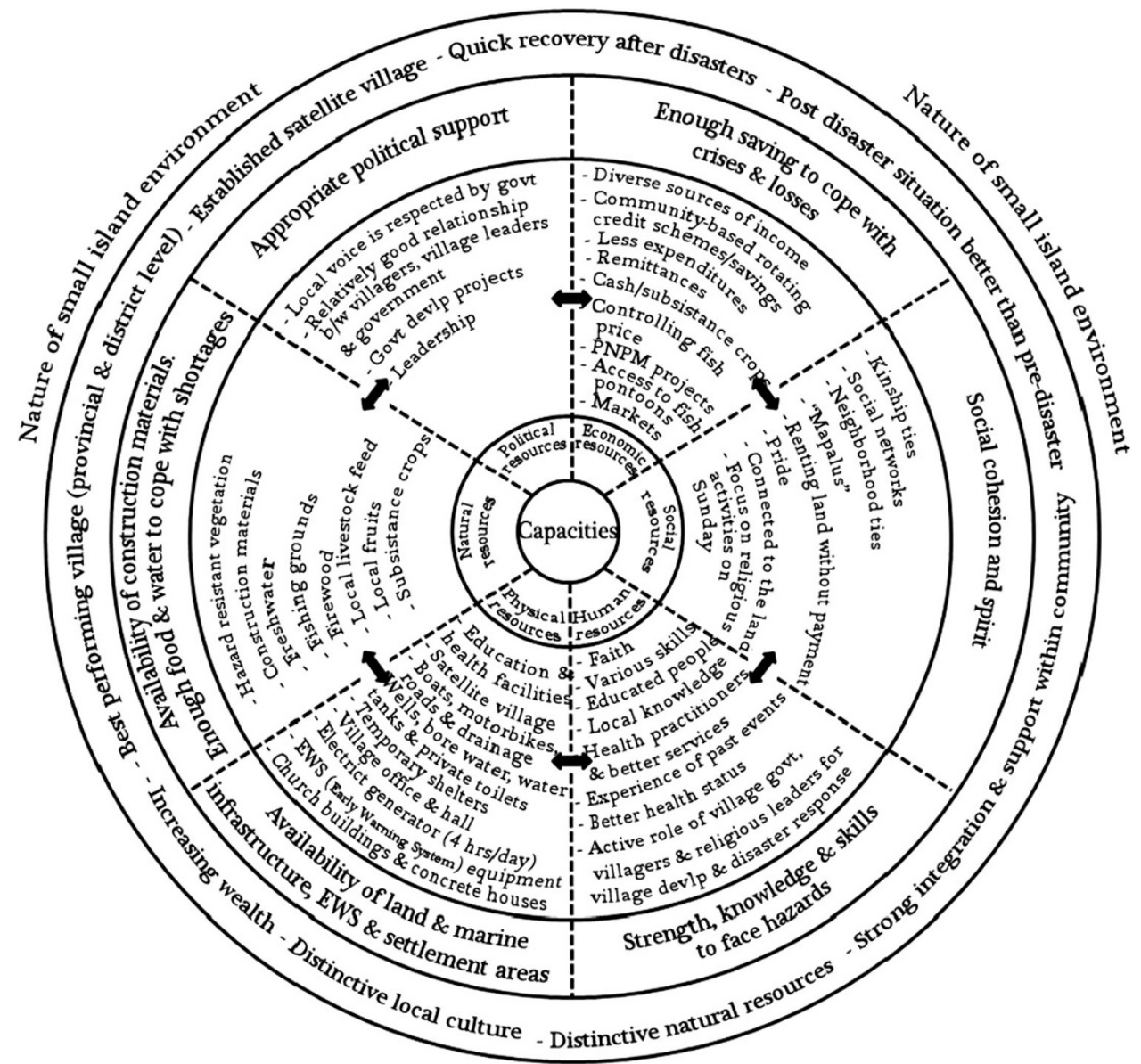

In spite of government attempts to prevent them from doing so, the villagers decided to return to Laingpatehi three years after the eruption. They organized themselves through the traditional Mapalus system to begin cleaning the village site and rebuild the church and houses. All the houses and buildings (church, primary and secondary schools, village office, and other public facilities) were buried in thick layers $(\sim 4 \mathrm{~m})$ of dust and gravel. The villagers demonstrated the strength of their social organization in restoring much of the village to standards higher than those prevailing before the eruption. The local availability of gravel, sand, and rocks helped this process. Subsequently villagers reported that the government did provide additional corrugated tin for roofing and some other building materials, but only after the villagers had finished cleaning and rebuilding many of the houses.

The area available for planting tree crops and vegetables had been damaged by the eruption. Few coconut trees survived and the volcanic debris that now covered the island was not suitable for growing the traditional vegetables-spinach, snake bean, chili, tomatoes, and Chinese vegetables. The people were only able to grow cassava, bananas, and an edible hibiscus used as a vegetable. The result of the eruption was that their terrestrial cash crop production was limited to small quantities of copra and limited amounts of cassava (processed into flour) to sell on Tagulandang Island. The strategy for coping with these constraints is influenced by the spirit of togetherness. Villagers who have insufficient land are allowed to grow cash or subsistence crops on the other villagers' land. This has allowed villagers with insufficient land to plant and benefit from coconut palms. They agree to plant coconut trees for the land owner in exchange for the right to cultivate vegetables between the palm trees, or share the coconut production. The trees became the property of the land owner once they had grown big enough to shade out the vegetables beneath them.

The villagers thus demonstrated an ability to identify and exploit new income generating opportunities and strategies in facing environmental stresses and space limitations. Figure 8 shows how the different assets interacted to enable the community to cope and succeed. The capacity framework for Laingpatehi village resulted from various methods applied in this study, mainly participatory activities. The key asset identified by villagers during participatory activities and later confirmed in the second period of 
fieldwork was the degree to which social cohesion was reinforced by Church activities. This finding was also confirmed by the head of the subdistrict (Makanoneng 2012). The community has the ability to self-organize to deal with new challenges. Strict observance of the Sabbath (on Sunday, the day of rest in Christianity, all villagers focus on Church-related activities), with a total unwritten ban on farming and fishing, and observance of the spirit of Mapalus is an indication of the role of the church in facilitating social cohesion. All villagers said their faith and togetherness helped them cope with difficulties and hazards in living on their small island.

Decentralization and the establishment of the district administration for Sitaro in 2007 was a significant positive development in Laingpatehi. This enabled better district government services to reach the island (Tamudia 2012). Commercial transportation, vital for small island regions, from district headquarters on the main islands of Siau, Tagulandang, and Biaro to Manado is now available daily (Fig. 4), whereas in earlier times ferries only ran three times a week. Additional ferries to the international seaport in Bitung on mainland Sulawesi have also aided the islanders. Development budget allocations from the central government to the Sitaro Archipelagic district government increased significantly from IDR 133.3 billion in 2012 (USD 12 million) to IDR 370.5 billion in 2013 (USD 33 million) ( 1 USD $=11,000$ IDR, Indonesian rupiah) (Supit 2012). This enabled the district administration to increase the development budget allocations to all the villages in the district (Supit 2012). Laingpatehi village, for example, received a significant increase in its annual budget for village development (ADD-Alokasi Dana Desa, Village allocation funds) from IDR 25 million in 2010 (USD 2,200) to almost IDR 300 million in 2013 (USD 27,200) (Pemerintah Kecamatan Tagulandang 2013). These funds enabled them to develop village facilities including a new village office and community hall. Government indicators of economic growth in Sitaro District increased from $4.88 \%$ in 2006 to $8.11 \%$ in 2012. The district level Human Development Index increased from 72.58 in 2009 to 75.88 in 2012 (Badan Perencanaan Pembangunan Daerah Kabupaten Kepulauan Sitaro 2010a; Badan Pusat Statistik Kabupaten Kepulauan Sitaro 2012). These achievements have led to reduced poverty in the district (Pemerintah Kecamatan Tagulandang 2013; Manado Post 2013). The district governance contribution to the development processes was recognized by awards from the central government in 2008, 2009, 2011, and 2012 (opinion report from $B P K$ RI-The Audit Board of The Republic of Indonesia) (Tribun Manado 2013). This indicates relatively good and clean governance.
In the years following the return to Laingpatehi, the village received several regional awards (2009 and 2010) for high levels of achievement in the governance system, health, economic and education status, security, local institutional performance, local participation, and family welfare (PKK-women's family welfare organization. This is a hierarchal organization of government officers' wives working at all level of government institutions, including village offices) (Fig. 8). These awards facilitated and motivated the improvement of village government services, Mapalus and local group activities, and attracted additional funding from district authorities (Makanoneng 2012). Villagers also reported support for fishermen and farmers in the village such as fishing boats, boat engines, seeds, and tools for fishing and farming. A national program for community empowerment (PNPM) contributed to many village improvements, including a diesel generator for electricity, footpaths to crop areas, drainage ditches, and loans for community-based rotating credit and savings schemes.

\section{Small Island Communities' Capacities in Facing Multiple Hazards: Their Strength and Innovation}

The main lesson from this account of the events in Laingpatehi is that the strong social cohesion of the villagers, much of it centered on their church, enabled them to return and reconstruct their village to a better standard than its pre-eruption 2002 level: concrete houses, most with tiled roofs and indoor toilets, improved standards of sanitation; and a concrete village road and concrete footpath to Pumpente, provided safe access to the boats going to Tagulandang Island during periods of strong winds (Fig. 9). The networks the villagers established while living in the temporary settlement enabled them to learn new fishing techniques that allowed further diversification of their livelihoods. This diversification strategy enabled them to cope with hardship situations (Scoones 1998) and to rebuild their lives.

Diversity and social cohesion alone would not be sufficient to enable Laingpatehi to prosper. Substantial support came from district government at critical times. Support in the form of building materials, daily transportation services to connect with the mainland and district government center, sufficient village budget allocations, and other current government projects (secondary and high school building with its facilities) enabled the people of Laingpatehi to develop stronger livelihoods. The strengths of the villagers in rebuilding their village combined with the policy of district government that heavily focused on community development (Badan Perencanaan Pembangunan Daerah Kabupaten Kepulauan Sitaro 2010a). 


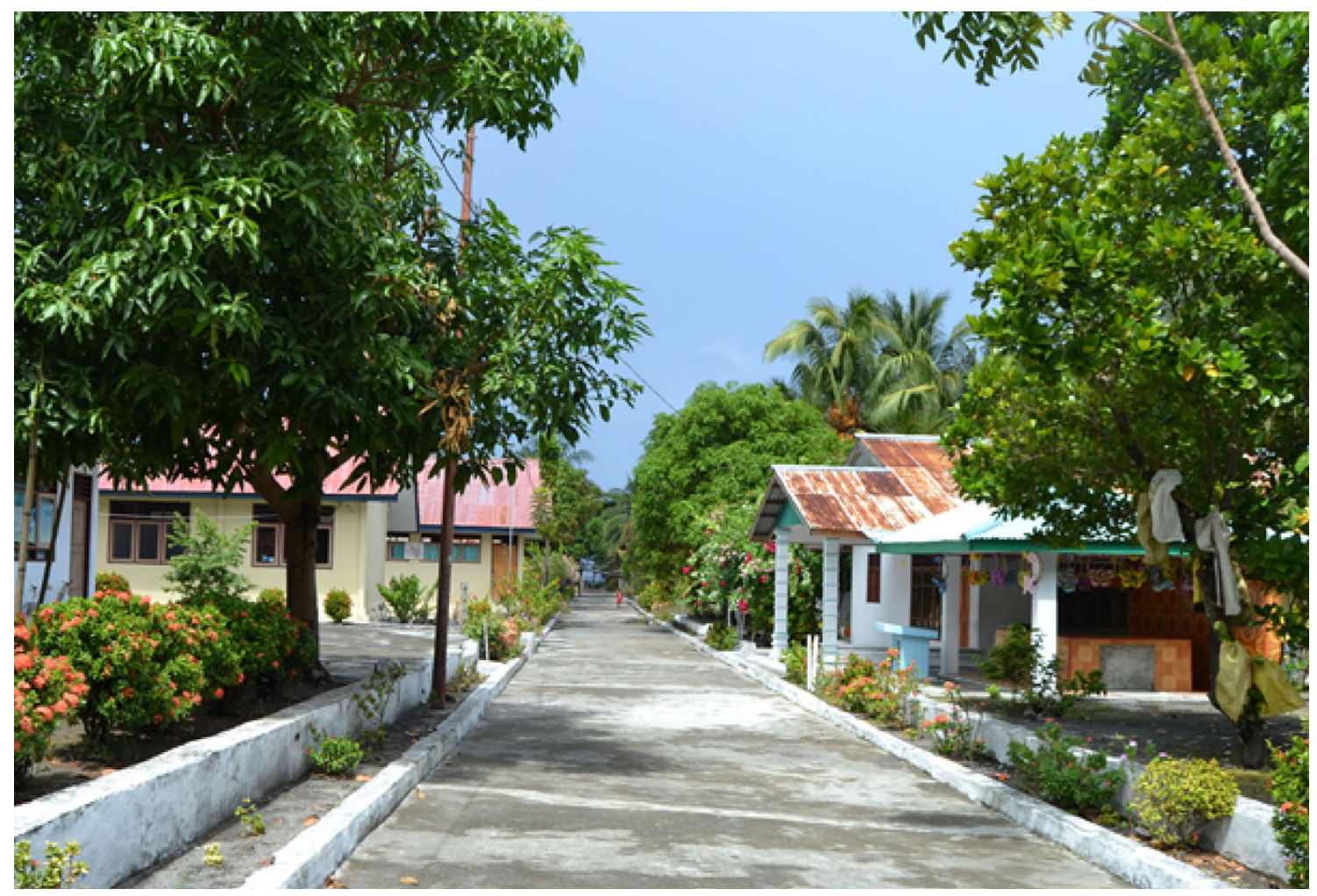

Fig. 9 The main street of Laingpatehi village in 2012 - everything visible has been totally reconstructed by the community since the volcanic eruption of 2002. Photograph by Mercy M.F. Rampengan, July 2012

The villagers' strong spirit and strength in working together to find solutions after the disaster, in spite of the limitations of the island environment, demonstrate the claims of Anderson and Woodrow (1989) that those affected by disasters have capacity to rebuild their lives. The faith and togetherness of islanders reflect their social resources that act as a social glue that holds them together in facing disturbances (Giavelli and Rossi 1990; Anckar and Anckar 1995; Skelton 2007).

The Laingpatehi community exploits rich fishing grounds close to the island and has access to distant plantations. The income and seasonal employment availability from the satellite village in Laolalang and from remittances all strengthen the community in ways described by Tobin (1999), that is, social networks contribute to sustainability of communities in facing hazards. Livelihood diversity is an essential ingredient of local capacity as in the case of people living around Mt. Pinatubo in the Philippines (Gaillard 2006). Diverse but socially cohesive communities are able to "live with risk" and build resilience to external shocks (Tobin 1999; UNISDR 2004).

The "endogenous hazards" and "intrinsic vulnerability" that exist on the island (Pelling and Uitto 2001; Lewis 2009) can be understood as a complex reality. This condition cannot be avoided under the limited space and biophysical constraints of small islands, but can become a source of strength and innovation for the community.

Taleb (2012) has described the way in which exposure to challenges can strengthen individuals, communities, and organizations. Laingpatehi has such qualities that have been strengthened by the challenges to which they have been exposed. Davis et al. (2004) use social vulnerability and capacity analysis to investigate how a vulnerable community may succeed. This underlines the fact that vulnerable people have capacity to support them in times of hardship. The experience of Laingpatehi villagers, who are vulnerable to volcanic eruptions and other hazards, of rebuilding their village with their own resources after the 2002 eruption and subsequently receiving government awards for their achievements in 2009 and 2010, shows how they have been resilient and have rebuilt their settlement. They benefited from their "uncomfortable" living experience in the temporary settlement by learning how to change their fishing strategy and use fishing pontoons. These perspectives are significant and should be considered in future disaster studies. People living in hazard prone areas can use hazards and disasters as a chance and motivation to find better livelihoods. The spirit and strategies help them to persist and prosper in the face of adverse conditions. 
Cooperation does not always occur when people are challenged, although it is more difficult to document these instances in the shadow of Laingpatehi's success in performing cooperative actions. It has been argued that marginal people may be excluded in cooperation because of poor relationships and lack of integration of these people within a society (Susman et al. 1983). This may lead to these people being rejected (Shields 1991) and possibly further marginalized socially (Wisner 1993; Wisner et al. 2004). The research in Laingpatehi, despite the extensive use of qualitative methods, did not uncover instances of exclusion.

The villagers' willingness to learn and flexibility and readiness to adjust to changing conditions were crucial ingredients for successful livelihoods. This diverse portfolio of activities, in conjunction with their strong social cohesion, enabled them to not only survive, but to construct better physical and social structures. This is a result of the livelihood diversification strategies as identified elsewhere by Ellis (1999). Inhabitants of small islands perceive the surrounding sea as integral to their lives, not as an isolating barrier (McCall 1994). This encourages the continuing construction of a diverse livelihood portfolio that has proven successful in the past.

The initiative taken by the villagers in establishing a satellite village in Central Sulawesi for the exploitation of nutmeg and cloves as cash crops shows an ability to exercise collective entrepreneurialism. This is consistent with the argument put forth by Sandler (1992) who has shown that in particularly demanding circumstances groups of people will act in a cooperative manner. Pungetti (1995) has shown similar social bonding in Sardinia in managing agricultural activities.

The strategies utilized and exhibited by the Laingpatehi villagers, in tandem with government support, created a comprehensive combination and interaction among resources that determines local capacity. This can be seen in the outcomes they have achieved (Fig. 8). Achieving quick recovery following a disaster is a livelihood outcome that is closely associated with natural, human, political, and social forms of resources. These outcomes are under the constraints of a small island environment. But such constraints can be media for a small island community to be stronger and innovative in developing sustainable livelihoods.

\section{Conclusion}

Access to resources, attachment to places, and aesthetics are the main reason why people live in dangerous areas (Tuan 1974, 1977; Duncan et al. 1981; Jackson 2001; Cannon 2008). The Laingpatehi community inhabits an area that others might consider excessively hazardous.
While living in the shadow of hazards they have taken initiatives that have resulted in stronger, diversified livelihoods. Therefore, remoteness, limited natural resources, and hazard risks, rather than just being sources of vulnerability, can be sources of innovation and strength and have helped to create diverse livelihoods.

The social, cultural, and economic dynamics of Laingpatehi villagers in fulfilling their livelihood needs shows how strong a small island community can be in facing natural hazards. By living with hazards, the community has been forced to diversify its livelihoods, thus increasing their capacity by being more innovative. Support from government was also important and a combination of local strength and external support helped to achieve positive outcomes.

This study has shown that the marginalization-vulnerability nexus can be offset by capacity and social cohesion towards improved livelihoods. Disaster risk reduction strategies should give greater emphasis to building livelihood resources as a basis for strengthening local capacity and vice versa. The conventional approach of seeking to reduce risks through building protective infrastructure should be combined with approaches that increase local capacity (Hewitt 1983, 2007; Weichselgartner and Obersteiner 2002; Bankoff et al. 2004; Allen 2006; Mercer et al. 2007; Gaillard 2010; Gaillard and Mercer 2012; Wisner et al. 2012). In particular, the complex reality of small island environments that brings vulnerability to the fore can in fact facilitate the emergence of strength and innovation in the communities. Therefore, physical mitigation should be de-prioritized, and supporting livelihood resources to increase flexibility and diversity is of the utmost concern.

Open Access This article is distributed under the terms of the Creative Commons Attribution License which permits any use, distribution, and reproduction in any medium, provided the original author(s) and the source are credited.

\section{References}

Allen, K.M. 2006. Community-based disaster preparedness and climate adaptation: Local capacity-building in the Philippines. Disasters 30(1): 81-101.

Anckar, D., and C. Anckar. 1995. Size, insularity and democracy. Scandinavian Political Studies 18(4): 211-227.

Anderson, M.B., and P.J. Woodrow. 1989. Rising from the ashes: Development strategies in times of disasters. Boulder: Westview Press.

Badan Perencanaan Pembangunan Daerah Kabupaten Kepulauan Sitaro (Sitaro District Regional Development Planning Board). 2010a. Excellent potential and investment prospects in the district of Siau Tagulandang and Biaro (Potensi unggulan dan prospek investasi di Kabupaten Kepulauan Siau Tagulandang Biaro). Forum temu usaha pemerintah Kabupaten Siau, Tagulandang dan Biaro, Manado (in Indonesian). 
Badan Perencanaan Pembangunan Daerah Kabupaten Kepulauan Sitaro (Sitaro District Regional Development Planning Board). 2010b. Final report: Survey mapping of disaster prone areas (Laporan akhir: Pekerjaan penyusunan profil daerah rawan bencana). Ondong: PT. Marliota Tumbet Abadi (in Indonesian).

Badan Perencanaan Pembangunan Daerah Kabupaten Kepulauan Sitaro (Sitaro District Regional Development Planning Board). 2012. Map of vulnerable areas of Sitaro Archipelagic District and its surrounding areas (Peta rawan bencana kawasan Pulau Siau dan sekitarnya). Siau: Bappeda Kab. Kep. Sitaro (in Indonesian).

Badan Pusat Statistik Kabupaten Kepulauan Sitaro (Central Bureau of Statistics of Sitaro District). 2012. Siau Tagulandang Biaro archipelago in figures 2012. Tahuna: Badan Pusat Statistik Kabupaten Kepulauan Sitaro.

Bankoff, G. 2004. Cultures of disaster: Society and natural hazard in the Philippines. London and New York: RoutledgeCurzon.

Bankoff, G., G. Frerks, and D. Hilhorst. 2004. Mapping vulnerability: Disasters, development, and people. London: Earthscan.

Becker, J., D. Johnston, H. Lazrus, G. Crawford, and D. Nelson. 2008. Use of traditional knowledge in emergency management for tsunami hazard: A case study from Washington State USA. Disaster Prevention and Management 17(4): 488-502.

Beller, W. 1990. How to sustain a small island. In Sustainable development and environmental management of small islands, 5th ed, ed. W.S. Beller, P.G. d'Ayala, and P. Hein, 15-22. Paris: Parthenon Publishing Group.

Binternagel, N.B., J. Juhrbandt, S. Koch, M. Purnomo, S. Schwarze, J. Barkmann, and H. Faust. 2010. Adaptation to climate change in Indonesia-Livelihood strategies of rural households in the face of ENSO related droughts. In Tropical rainforests and agroforests under global change, ed. R. Allan, U. Förstner, and W. Salomons, 351-375. Berlin: Springer.

Briguglio, L. 1995. Small island developing states and their economic vulnerabilities. World Development 23(9): 1615-1632.

Brilman, D. 2000. Good news from the edge of Pacific (Kabar baik di bibir Pasifik) (L. Wuaten, C. Lantemona-Tusaoh, H.L.A. Salamata-Joseph, T.J. Edeiman, A. Kansil-Kaloke, and C. HenochBastiaan, Trans.). Jakarta: Badan Pekerja Sinode GMIST \& Pustaka Sinar Harapan.

Brookfield, H. 1990. An approach to islands. In Sustainable development and environmental management of small islands, 5th ed, ed. W.S. Beller, P.G. d'Ayala, and P. Hein, 23-34. Paris: Parthenon Publishing Group.

Burton, I., R.W. Kates, and G.F. White. 1993. The environment as hazard, 2nd ed. New York: Guilford Press.

Cadag, J.R.D., and J.C. Gaillard. 2013. Integrating people's capacities in disaster risk reduction through participatory mapping. In Disaster management: International lessons in risk reduction, response and recovery, ed. A. Lopez-Carresi, M. Fordham, B. Wisner, I. Kelman, and J.C. Gaillard, 269-286. London: Earthscan.

Campbell, J.R. 1984. Dealing with disaster: Hurricane response in Fiji. Honolulu: Government of Fiji and Pacific Islands Development Program, East-West Center.

Campbell, J.R. 2006. Traditional disaster reduction in Pacific island communities. Avalon, New Zealand: GNS Science Report 2006/38.

Campbell, J.R. 2009. Islandness: Vulnerability and resilience in Oceania. Shima: The International Journal of Research into Island Cultures 3(1): 85-97.

Cannon, T. 2008. Vulnerability, "innocent" disasters and the imperative of cultural understanding. Disaster Prevention and Management 17(3): 350-357.

Cannon, T., J. Twigg, and J. Rowell. 2003. Social vulnerability, sustainable livelihoods and disasters. London: Department for International Development (DFID).
Chambers, R. 1994. Participatory rural appraisal (PRA): Analysis of experience. World Development 22(9): 1253-1268.

Chambers, R. 2006. Vulnerability, coping and policy (editorial introduction). IDS Bulletin 37(4): 33-40.

Chambers, R., and G. Conway. 1992. Sustainable rural livelihoods: Practical concepts for the 21st century, Discussion Paper 296. Brighton, UK: Institute of Development Studies, University of Sussex.

Chester, D.K., A.M. Duncan, and C.J.L. Dibben. 2008. The importance of religion in shaping volcanic risk perception in Italy, with special reference to Vesuvius and Etna. Journal of Volcanology and Geothermal Research 172(3-4): 216-228.

Cosgrove, D. 1996. Ideas and culture: A response to Don Mitchell. Transactions of the Institute of British Geographers 21(3): 574-575.

Coulthard, S. 2008. Adapting to environmental change in artisanal fisheries-Insights from a South Indian lagoon. Global Environmental Change 18(3): 479-489.

Cronin, S.J., D.R. Gaylord, D. Charley, B.V. Alloway, S. Wallez, and J.W. Esau. 2004. Participatory methods of incorporating scientific with traditional knowledge for volcanic hazard management on Ambae Island, Vanuatu. Bulletin of Volcanology 66(7): 652-668.

Davis, I., B. Haghebeart, and D. Peppiatt. 2004. Social vulnerability and capacity analysis. Geneva: Provention Consortium.

Dazé, A., K. Ambrose, and C. Ehrhart. 2009. Climate vulnerability and capacity analysis handbook. Geneva: Care International.

Departemen Pekerjaan Umum Republik Indonesia. 2008. Profile Balai Wilayah Sungai Sulawesi I (Profil Balai Wilayah Sungai I). Manado: Balai Wilayah Sungai Sulawesi I (in Indonesian).

Duncan, J., and N. Duncan. 1996. Reconceptualizing the idea of culture in geography: A reply to Don Mitchell. Transactions of the Institute of British Geographers 21(3): 576-579.

Duncan, A.M., D.K. Chester, and J.E. Guest. 1981. Mount Etna volcano: Environmental impact and problems of volcanic prediction. The Geographical Journal 147(2): 164-178.

Ellis, F. 1999. Rural livelihood diversity in developing countries: Evidence and policy implications. London: Overseas Development Institute.

Gaillard, J.C. 2006. Traditional societies in the face of natural hazards: The $1991 \mathrm{Mt}$. Pinatubo eruption and the Aetas of the Philippines. International Journal of Mass Emergencies and Disasters 24(1): 5-43.

Gaillard, J.C. 2007. Resilience of traditional societies in facing natural hazards. Disaster Prevention and Management 16(4): $522-544$.

Gaillard, J.C. 2010. Vulnerability, capacity and resilience: Perspectives for climate and development policy. Journal of International Development 22(2): 218-232.

Gaillard, J.C., and J.R.D. Cadag. 2009. From marginality to further marginalization: Experiences from the victims of the July 2000 Payatas trashslide in the Philippines. JAMBA: Journal of Disaster Risk Studies 2(3): 197-215.

Gaillard, J.C., and V. Le Masson. 2007. Traditional societies' response to volcanic hazards in the Philippines. Mountain Research and Development 27(4): 313-317.

Gaillard, J.C., and J. Mercer. 2012. From knowledge to action: Bridging gaps in disaster risk reduction. Progress in Human Geography 37(1): 93-114.

Gaillard, J.C., E. Clavé, O. Vibert, Dedi Azhari, J.C. Denain, Y. Efendi, D. Grancher, et al. 2008. Ethnic groups' response to the 26 December 2004 earthquake and tsunami in Aceh Indonesia. Natural Hazards 47(1): 17-38.

Gaillard, J.C., E. Maceda, E. Stasiak, I. Le Berre, and M. Espaldon. 2009. Sustainable livelihoods and people's vulnerability in the face of coastal hazards. Journal of Coastal Conservation 13(2): $119-129$. 
Giavelli, G., and O. Rossi. 1990. Rational management in the small Mediterranean islands: Ecological and demographic evaluations. In Sustainable development and environmental management of small islands, 5th ed, ed. W.S. Beller, P.G. d'Ayala, and P. Hein, 119-140. Paris: Parthenon Publishing Group.

GVP (Global Volcanism Program). 2013. Smithsonian Institution National Museum of Natural History. http://www.volcano.si.edu/ volcano.cfm?vnum=0607-01=. Accessed 16 Jun 2013.

Hadad, E., and A. Hamid. 1990. Exploring the diversity of nutmeg in Maluku Utara region (Mengenal berbagai plasma nutfah pala di daerah Maluku Utara). Bogor: Balai Penelitian Tanaman Rempah dan Obat (in Indonesian).

Hewitt, K. 1983. The idea of calamity in a technocratic age. In Interpretations of calamity from the viewpoint of human ecology, ed. K. Hewitt, 3-32. London: Ellen \& Unwin.

Hewitt, K. 2007. Preventable disasters: Addressing social vulnerability, institutional risk, and civil ethics. Geographisches Rundschau: International Edition 3(1): 43-52.

Hewitt, K. 2009. Culture and risk: Understanding the sociocultural settings that influence risk from natural hazards. Synthesis report from a global E-Conference organised by ICIMOD and facilitated by the Mountain Forum Kathmandu. Kathmandu: International Centre for Integrated Mountain Development (ICIMOD).

Hovgaard, G. 2000. Globalisation, embeddedness and local coping strategies: A comparative and qualitative study of local dynamics in contemporary social change. Ph.D. thesis. Denmark: Roskilde University.

IFRC (International Federation of Red Cross and Red Crescent). 2007. VCA toolbox: With references sheets. Geneva: IFRC.

Ivanitz, M. 1999. Culture, ethics and participatory methodology in cross-cultural research. Australian Aboriginal Studies 2: 46-58.

Jackson, J. 2001. Living with earthquakes: Know your faults. Journal of Earthquake Engineering 5(sup001): 5-123.

Kantor Kecamatan Tagulandang (Office of Tagulandang Sub-District). 2011. Tagulandang in figures 2011. Tagulandang: Kecamatan Tagulandang (in Indonesian).

Kelman, I. 2010. Hearing local voices from Small Island Developing States for climate change. Local Environment 15(7): 605-619.

Kelman, I., and T.A. Mather. 2008. Living with volcanoes: The sustainable livelihoods approach for volcano-related opportunities. Journal of Volcanology and Geothermal Research 172(3-4): 189-198.

Kelman, I., J. Lewis, J.C. Gaillard, and J. Mercer. 2011. Participatory action research for dealing with disasters on islands. Island Studies Journal 6(1): 59-86.

Kelman, I., J. Mercer, and J.J. West. 2009. Combining different knowledges: Community-based climate change adaptation in small island developing states. Participatory Learning and Action 60(1): 41-53.

Kemper, E.A., S. Stringfield, and C. Teddlie. 2003. Mixed methods sampling strategies in social science research. In Handbook of mixed methods in social and behavioral research, ed. A. Tashakkori, and C. Teddlie, 273-296. Thousand Oaks, CA: Sage.

Kuban, R., and H. MacKenzie-Carey. 2001. Community-wide vulnerability and capacity assessment (CVCA). Ottawa: Office of Critical Infrastructure Protection and Emergency Preparedness.

Kumar, S. 2002. Methods for community participation: A complete guide for practitioners. Warwickshire: Intermediate Technology Publications.

Lavigne, F., B. De Coster, N. Juvin, F. Flohic, J.C. Gaillard, P. Texier, J. Morin, and J. Sartohadi. 2008. People's behaviour in the face of volcanic hazards: Perspectives from Javanese communities, Indonesia. Journal of Volcanology and Geothermal Research 172(3-4): 273-287.

Le De, L., J.C. Gaillard, and W. Friesen. 2013. Remittances and disaster: A review. International Journal of Disaster Risk Reduction 4(1): 34-43.
Lewis, J. 2009. An island characteristic: Derivative vulnerabilities to indigenous and exogenous hazards. Shima: The International Journal of Research into Island Cultures 3(1): 3-15.

Makanoneng, J. 2012. Personal communication. The office of the Head of Sub-District of Tagulandang, Bahoi. Accessed 10 July 2012.

Manado Post. 2013. Sitaro is the most properous (Sitaro paling sejahtera). http://epaper.mdopost.com. Accessed 27 Jun 2013 (in Indonesian).

Manginsela-Tiendas, P.N. 2001. Collection of letters from the Pastor Kelling during his services in Ulu Siau and Tagulandang from 1859 to 1899 (Kumpulan surat-surat Pendeta F. Kelling selama pelayanan di Ulu Siau dan Tagulandang pada tahun 1859 1899). Siau: GMIST (in Indonesian).

Marks, S., and J. Pomeroy. 1995. International trade in nutmeg and mace: Issues and options for Indonesia. Bulletin of Indonesian Economic Studies 31(3): 103-118.

Marshall, C., and G.B. Rossman. 2006. Design qualitative research, 4th ed. Thousand Oaks, CA: Sage.

McAdoo, B.G., L. Dengler, G. Prasetya, and V. Titov. 2006. Smong: How an oral history saved thousands on Indonesia's Simeulue island during the December 2004 and March 2005 Tsunamis. Earthquake Spectra 22(S3): S661-S669.

McAdoo, B., A. Moore, and J. Baumwoll. 2009. Indigenous knowledge and the near field population response during the 2007 Solomon Islands tsunami. Natural Hazards 48(1): 73-82.

McCall, G. 1994. Nissology: A proposal for consideration. Journal of the Pacific Society 17(2-3): 93-106.

Méheux, K., D. Dominey-Howes, and K. Lloyd. 2007. Natural hazard impacts in small island developing states: A review of current knowledge and future research needs. Natural Hazards 40(2): 429-446.

Mercer, J., and I. Kelman. 2010. Living alongside a volcano in Baliau, Papua New Guinea. Disaster Prevention and Management 19(4): $412-422$.

Mercer, J., D. Dominey-Howes, I. Kelman, and K. Lloyd. 2007. The potential for combining indigenous and western knowledge in reducing vulnerability to environmental hazards in small island developing states. Environmental Hazards 7(4): 245-256.

Mercer, J., J.C. Gaillard, K. Crowley, R. Shannon, B. Alexander, S. Day, and J. Becker. 2012. Culture and disaster risk reduction: Lessons and opportunities. Environmental Hazards 11(2): 74-95.

Mercer, J., I. Kelman, S. Suchet-Pearson, and K. Lloyd. 2009. Integrating indigenous and scientific knowledge base for disaster risk reduction in Papua New Guinea. Geografiska Annaler: Series B, Human Geography 91(2): 157-183.

Mitchell, D. 1995. There's no such thing as culture: Towards a reconceptualization of the idea of culture in geography. Transactions of the Institute of British Geographers 20(1): 102-116.

Morrice, M.G., P.A. Jezek, J.B. Gill, D.J. Whitford, and M. Monoarfa. 1983. An introduction to the Sangihe arc: Volcanism accompanying arc-arc collision in the Molucca Sea, Indonesia. Journal of Volcanology and Geothermal Research 19(1-2): 135-165.

Mula, R.P. 1999. Coping with mother nature: Households, livelihood security and coping strategies in a situation of a continuing disaster in Tarlac, Philippines. Ph.D. thesis. Landbouwuniversiteit Wageningen Netherlands.

Novarianto, H. 2010. Siau nutmeg revitalization in North Sulawesi (Revitalisasi perkebunan pala Siau, Sulawesi Utara). Warta Penelitian dan Pengembangan Pertanian 32(1): 4-6 (in Indonesian).

Paris, R., A.D. Switzer, M. Belousova, A. Belousov, B. Ontowirjo, P.L. Whelley, and M. Ulvrova. 2014. Volcanic tsunami: A review of source mechanisms, past events and hazards in Southeast Asia (Indonesia, Philippines, Papua New Guinea). Natural Hazards 70(1): 447-470. 
Paton, D. 2006. Disaster resilience: Building capacity to co-exist with natural hazards and their consequences. In Disaster resilience: An integrated approach, ed. D. Paton, and D. Johnston, 3-10. Springfield, IL: Charles C Thomas Publisher.

Pelling, M., and J.I. Uitto. 2001. Small island developing states: Natural disaster vulnerability and global change. Global Environmental Change Part B: Environmental Hazards 3(2): 49-62.

Pemerintah Kecamatan Tagulandang (Government of Tagulandang Sub-District). 2013. Village budget allocation (ADD) in Tagulandang Sub-District (Alokasi Dana Desa (ADD) di Kecamatan Tagulandang) Bahoi: Kantor Kecamatan Tagulandang (in Indonesian).

Pemerintah Kabupaten Sitaro (Government of Sitaro District). 2012. Sitaro is the lowest receiver district for Raskin program (rice for the poor family) in North Sulawesi Province (Sitaro adalah kabupaten penerima Raskin terendah di Propinsi Sulawesi Utara). http://sitarokab.go.id/berita-151-sitaro-terendah-penerima-raskinsesulut-html. Accessed 20 Mar 2012 (in Indonesian).

Pungetti, G. 1995. Anthropological approach to agricultural landscape history in Sardinia. Landscape and Urban Planning 31(1): 47-56.

Rahman, M.A., and O. Fals-Borda. 1991. A self-review of PAR. London: Intermediate Technology Publications.

Reenberg, A., T. Birch-Thomsen, O. Mertz, B. Fog, and S. Christiansen. 2008. Adaptation of human coping strategies in a small island society in the SW pacific - 50 years of change in the coupled human-environment system on Bellona, Solomon Islands. Human Ecology 36(6): 807-819.

Sanderson, D. 2000. Cities, disasters and livelihoods. Environment and Urbanization 12(2): 93-102.

Sandler, T. 1992. Collective action: Theory and applications. Ann Arbor: University of Michigan Press.

Sayer, J., and B. Campbell. 2004. The science of sustainable development: Local livelihoods and the global environment. Cambridge: Cambridge University Press.

Schwarz, A.-M., C. Béné, G. Bennett, D. Boso, Z. Hilly, C. Paul, R. Posala, S. Sibiti, et al. 2011. Vulnerability and resilience of remote rural communities to shocks and global changes: Empirical analysis from Solomon Islands. Global Environmental Change 21(3): 1128-1140.

Scoones, I. 1998. Sustainable rural livelihoods: A framework for analysis. Sussex: Institute of Development Studies.

Scoones, I. 2009. Livelihoods perspectives and rural development. Journal of Peasant Studies 36(1): 171-196.

Sen, A. 1981. Ingredients of famine analysis: Availability and entitlements. The Quarterly Journal of Economics 96(3): 433-464.

Shekelle, M., C. Groves, S. Merker, and J. Supriatna. 2008. Tarsius tumpara: A new tarsier species from Siau Island, North Sulawesi. Primate Conservation 23(1): 55-64.

Shields, R. 1991. Places on the margin: Alternative geographies of modernity. London: Routledge.

Skelton, T. 2007. Islands for the young: Culture and development for all. Singapore Journal of Tropical Geography 28(2): 136-138.

Supit, T. 2012. Personal communication. The office of the Regent of Sitaro, Ondong. Accessed 26 November 2012.

Susman, P., P. O'Keefe, and B. Wisner. 1983. Global disasters, a radical interpretation. In Interpretations of calamity, ed. K. Hewitt, 3-32. Boston: Allen \& Unwin.

Swanson, K. 2008. Witches, children and Kiva-the-research-dog: Striking problems encountered in the field. Area 40(1): 55-64.

Taleb, N.N. 2012. Antifragile: Things that gain from disorder. New York: Random House Digital.

Taman Budaya Manado (Manado Cultural Center). 1991. Report: Arts and culture inventory in North Sulawesi(Sangihe Talaud)
(Laporan: Inventarisasi seni budaya daerah Sulawesi Utara (Sangihe Talaud)). Manado: Taman Budaya Manado (in Indonesian).

Tamudia, D. 2012. Personal communication. The office of the Chairman of Parliament of Sitaro, Siau. Accessed 12 November 2012.

Terry, J.P., and J.R. Goff. 2012. The special vulnerability of AsiaPacific islands to natural hazards. In Natural hazards in the AsiaPacific region: Recent advances and emerging concepts, ed. J.P. Terry, and J.R. Goff, 3-6. London: The Geological Society.

Tobin, G.A. 1999. Sustainability and community resilience: The holy grail of hazards planning? Global Environmental Change Part B: Environmental Hazards 1(1): 13-25.

Tribun Manado (Tribun Manado Newspaper). 2013. Diverse achievements of Sitaro from 2008 to 2012 (Sitaro torehkan beragam prestasi dari 2008-2012). http://manado.tribunnews.com/2013/ 09/10/sitaro-torehkan-beragam-prestasi-dari-2008-2012. Accessed 31 Oct 2013 (in Indonesian).

Tuan, Y.-F. 1974. Topophilia. Englewood Cliffs, NJ: Prentice-Hall.

Tuan, Y.-F. 1977. Space and place: The perspective of experience. Minneapolis: University of Minnesota Press.

Twigg, J. 2001. Sustainable livelihoods and vulnerability to disasters, Disaster Management Working Paper (Vol. 2). Benfield Greig Hazard Research Center.

UNDP (United Nations Development Programme). 2000. Human development report. Oxford: Oxford University Press.

UNESCO (United Nations Educational, Scientific and Cultural Organization). 1992. Small tropical islands, water resources of paradises lost, IHP Humid Tropics Programme Series No. 2. Paris: UNESCO.

UNISDR (United Nations International Strategy for Disaster Reduction). 2004. Living with risk-A global review of disaster reduction initiatives, vol. 1 and 2. Geneva and New York: United Nations.

Veitayaki, J. 2006. Caring for the environment and the mitigation of natural extreme events in Gau, Fiji islands: A self-help community initiative. Island Studies Journal 1(2): 239-252.

Watts, M.J., and H.G. Bohle. 1993. The space of vulnerability: The causal structure of hunger and famine. Progress in Human Geography 17(1): 43-67.

Weichselgartner, J., and M. Obersteiner. 2002. Knowing sufficient and applying more: Challenges in hazards management. Environmental Hazards 4(2-3): 73-77.

Wisner, B. 1993. Disaster vulnerability: Scale, power and daily life. GeoJournal 30(2): 127-140.

Wisner, B. 2001. Risk and the neoliberal state: Why post Mitch lessons didn't reduce El Salvador's earthquake losses. Disasters 25(3): 251-268.

Wisner, B. 2003. Sustainable suffering? Reflections on development and disaster vulnerability in the post-Johannesburg world. Regional Development Dialogue 24(1): 135-148.

Wisner, B., and J.C. Gaillard. 2009. An introduction to neglected disasters. JAMBA: Journal of Disaster Risk Studies 2(3): 151-158.

Wisner, B., P. Blaikie, T. Cannon, and I. Davis. 2004. At risk: Natural hazards, people's vulnerability and disasters, 2nd ed. London and New York: Psychology Press.

Wisner, B., J.C. Gaillard, and I. Kelman. 2012. Framing disaster: Theories and stories seeking to understand hazards, vulnerability and risk. In Handbook of hazards and disaster risk reduction, ed. B. Wisner, J.C. Gaillard, and I. Kelman, 18-34. London: Routledge. 